\title{
Knowing Killing and Environmental Law
}

Lisa Heinzerling

Georgetown University Law Center, heinzerl@law.georgetown.edu

This paper can be downloaded free of charge from:

https://scholarship.law.georgetown.edu/facpub/326

14 N.Y.U. Envtl. L.J. 521-534 (2006)

This open-access article is brought to you by the Georgetown Law Library. Posted with permission of the author. Follow this and additional works at: https://scholarship.law.georgetown.edu/facpub

Part of the Environmental Law Commons, and the Torts Commons 


\title{
GEORGETOWN LAW Faculty Publications
}

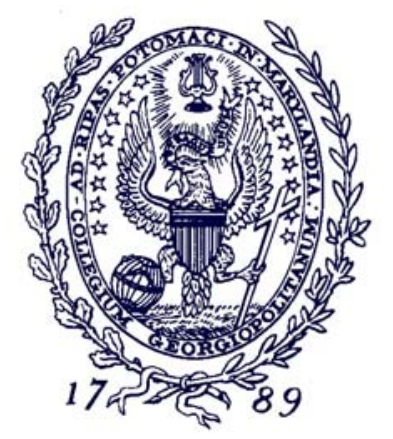

April 2010

\section{Knowing Killing and Environmental Law}

\author{
14 N.Y.U. Envtl. L.J. 521-534 (2006) \\ Lisa Heinzerling \\ Professor of Law \\ Georgetown University Law Center \\ heinzerl@law.georgetown.edu
}

This paper can be downloaded without charge from:

Scholarly Commons: http://scholarship.law.georgetown.edu/facpub/326/

Posted with permission of the author 


\section{ARTICLES}

\section{KNOWING KILLING AND ENVIRONMENTAL LAW}

\section{LISA HEINZERLING*}

My goal here is modest: I simply wish to defend the view that the moral commitment against knowing killing should play a role in decisions about environmental problems. In recent years, economic analysis has substantially succeeded in de-ethicizing environmental issues; this paper is part of an effort to re-ethicize them.

In previous work, I have criticized the use of cost-benefit analysis in making decisions about the environment. ${ }^{1}$ One source of my criticism has been the mismatch between moral values and economic valuation. I have, however, tended to leave the moral values I have defended rather vaguely defined. In this paper, I wish to identify one very specific, deeply embedded moral value and to explain its incompatibility with cost-benefit analysis.

The moral norm on which I will focus is the prohibition against murder-against the knowing killing of one person by another. This moral commitment is reflected in laws in all fifty U.S. states, in modern regulatory laws at the federal level, and in civil jury awards in tort cases involving profit-oriented corporations. This commitment is also reflected in otherwise disparate approaches to moral philosophy and in the moral traditions of all of the world's major religions. The moral value I am targeting is thus not a new norm, nor, in its traditional setting, a controversial one. But, as we will see, applying this norm outside its familiar contexts-including everyday shootings, stabbings, and the like-creates several complications.

* Professor of Law, Georgetown University Law Center. I am grateful to David Tarr for excellent research assistance and to Robin West for very helpful comments. A version of this paper was delivered at the 2005 University of North Carolina Environmental Symposium, "Perspectives on Environmental Values."

1 See, e.g., Frank ACKERMAN \& LiSA HEINZERLING, PRICELESS: ON KNOWING THE PRICE OF EVERYTHING AND THE VALUE OF NOTHING (2004). 
This norm surfaces in the environmental context because there are now clearly established links between many common environmental contaminants and human mortality. Fine particulates in the ambient air kill tens of thousands of people every year in the United States alone. ${ }^{2}$ Widely used chemicals such as vinyl chloride pose risks of lethal cancer and other diseases. $^{3}$ Greenhouse gases contributing to climate change will cause increased incidence of human disease, in addition to many other health-related effects. ${ }^{4}$ And so on. The basic idea is that pollution kills people and makes them sick, and, in many cases, we can expect death as a consequence of pollution.

Although I do not think there is much question as to the existence of a deeply embedded moral commitment against knowing killing, I would like to put a bit of flesh on the bones of that commitment by identifying several ways in which this moral norm is embedded in the U.S. legal system. This norm surfaces in three quite different legal contexts: traditional criminal law, modern environmental statutes, and tort law. In all three contexts, law corroborates the moral commitment I have identified. I do not claim that the technical elements of each legal standard are met in every case of environmental hazard, or that prosecutors should begin to bring scores of murder cases against polluters. My goal is merely to suggest that the moral commitment against knowing killing should play a role in environmental decisions. To that end, the second half of this essay considers the moral implications of cost-benefit analysis and how this approach may lead to a violation of the moral norm against knowing killing.

The most obvious area in which the norm against knowing killing is incorporated in the legal system is traditional criminal

2 See Deborah S. ShPrentz, Natural Res. Def. Council, BreathTAKING: Premature Mortality Due to Particulate Air Pollution in 239 AMERICAN CitIEs (1996); see also Douglas W. Dockery et al., An Association Between Air Pollution and Mortality in Six U.S. Cities, 329 NEw ENG. J. MED. 1753, 1755 (1993) (finding an approximately twenty-six percent increase in premature death attributable to fine-particulate air pollution).

3 See, e.g., Richard Lewis et al., Vinyl Chloride and Liver and Brain Cancer at a Polymer Production Plant in Louisville, Kentucky, 45 J. OCCUPATIONAL \& ENVTL. MED. 533 (2003).

4 See Nat'l Assessment Synthesis Team, U.S. Global Change Res. Program, Climate Change Impacts on the United States: The Potential Consequences of Climate VARIABILITy and Change, 102-07 (2000), available at http://www.usgcrp.gov/usgcrp/Library/nationalassessment/ overview.htm. 
law. Every state prohibits knowing killing. There are many different formulations of this basic prohibition. For sake of simplicity, here is the formulation offered by the highly influential Model Penal Code: murder is a homicide committed with the knowledge that death is "practically certain" to occur. ${ }^{5}$ Some states add the requirement of premeditation or "malice aforethought" (a famously problematic subject in criminal law): there must be some thought given to the killing before the killing occurs. $^{6}$ In a related vein, some states require a person to engage in a "careful weighing" of the factors behind the decision to kill in order for the killing to count as murder. ${ }^{7}$ Somewhat less serious penalties are attached to killings that result from moments of heated passion, in which the victim provokes the killer into an excusable rage or other agitated mental state. Here, the crime is typically viewed as manslaughter rather than murder. Specific legal formulations vary from state to state, but the underlying normative idea is clear enough: sober reflection on the decision whether to kill another human being makes the killing more problematic, from a moral perspective, than impulsive action in the heat of a difficult moment. Across a range of cases, therefore, murder might be said to be a crime of dispassion rather than of passion.

Thus, under our criminal laws, a person is a murderer if she engages in a course of conduct that she knows carries with it a practical certainty of death. To say that a person is a murderer is to deliver one of the most serious moral judgments our society makes. For murderers, we not only reserve some of the most severe penalties, including long jail time and possibly even death by execution, but also the most severe stigmatization and moral opprobrium. The punishment and the stigma identify the murderer as a person who has ranged far beyond society's bounds of

5 Model Penal Code $\S \S 2.02(2)(\mathrm{b})(\mathrm{ii}), 210.2(2002)$.

6 See, e.g., ARIZ. ReV. STAT. ANN. § 13-1105 (2001) (premeditation); Cal. PENAL CodE $\S 187$ (a) (West 1999) (malice aforethought); D.C. CoDE ANN. § 222101 (LexisNexis 2001) (premeditated malice); FLA. STAT. $\$ 782.04$ (1993) (premeditation).

${ }^{7}$ See, e.g., Kleve v. Hill, 202 F.3d 1155, 1157 (9th Cir. 2000) (characterizing premeditation as "careful weighing and pondering"); State v. Brown, 836 S.W.2d 530, 541 (Tenn. 1992) ("'[D]eliberation' is the process of carefully weighing such matters as the wisdom of going ahead with the proposed killing, the manner in which the killing will be accomplished, and the consequences which may be visited upon the killer if and when apprehended."). 
decency and good behavior.

The moral commitment against knowing killing can also be seen in modern regulatory statutes. Several modern environmental laws prohibit knowingly releasing hazardous substances into the air or water or onto the land with knowledge that these releases place another person in "imminent danger of death or serious bodily injury." These releases are criminal acts; for example, under the Clean Air Act, people who commit these acts may be sent to prison for up to fifteen years. ${ }^{9}$ Although here the offense is knowing endangerment, ${ }^{10}$ not knowing killing, the Clean Air Act's prohibition must flow from the general norm against knowing killing. Why would life-threatening endangerment matter if killing did not?

In early 2005 , a federal grand jury indicted the company W.R. Grace and several of its top corporate officials under this provision of the Clean Air Act. ${ }^{11}$ Among other allegations, the indictment states that W.R. Grace and its corporate officials violated the Clean Air Act by knowingly exposing the citizens of Libby, Montana, to asbestos-contaminated vermiculite ore without the citizens' knowledge or consent. ${ }^{12}$ One vivid example of how W.R. Grace and its officials allegedly treated the citizens of Libby is the company's provision of this contaminated ore to the high school to serve as the foundation for its running track. ${ }^{13}$ Another equally arresting example is the alleged provision of such ore to the elementary school to use as the foundation for a skating rink. ${ }^{14}$ The basic claim is that W.R. Grace and its officials knowing exposed the people of Libby to a life-threatening substance. It is hard to make sense of the normative underpinnings of the knowing endangerment provision at issue in the Grace case without recognizing the moral commitment against knowing killing.

8 See, e.g., 33 U.S.C. $\S 1319(3)(\mathrm{A})$ (2000) (water pollution); 42 U.S.C. $\S 6928(\mathrm{e})$ (2000) (hazardous waste); 42 U.S.C. $\$ 7413(\mathrm{c})(5)(\mathrm{A})$ (2000) (air pollution); see also, e.g., ARIz. REV. STAT. ANN. § 49-464(A) (2005); ARK. CoDE ANN. § 8-4-103(a)(2)(A) (2000); Colo. REV. STAT. § 25-7-122.1(3)(a) (2004); GA. CODE ANN. § 12-9-24(a) (2001).

942 U.S.C. $\S 7413(c)(5)(A)$.

10 See id.

11 Indictment ๆๆ 185-90, United States v. W.R. Grace, No. CR 05-07-MDWM (D. Mont. Feb. 7, 2005).

${ }_{12}$ Id. $9976,142$.

13 Id. ๆๆ $24,25,144$.

14 Id. 7 ๆ $141,142$. 
My last example of the norm against knowing killing in U.S. law comes from tort law. The legal "formula" for determining negligence - familiar to any first-year law student-holds that a person is negligent if the burdens of precaution (that is, the costs of avoiding the accident) are less than the costs of the accident multiplied by its probability. This formula, dubbed the "Hand" formula after the judge who first stated it in algebraic form, ${ }^{15}$ has inspired countless academic papers on the role of economics in tort law. ${ }^{16}$

But here is a funny thing: when private actors in court cases are shown to have actually used the Hand formula in the decisionmaking that preceded the injury or death that led to the tort casewhen private actors use cost-benefit analysis to decide whether, for example, to adopt a safer product design-they are severely punished for it. ${ }^{17}$

To take one famous example, when Ford declined to make design changes to its Pinto on the basis of a cost-benefit analysis purporting to show that the design changes cost more than the value of the safety benefits they would have provided, it was slapped with what was a huge punitive damages award: $\$ 125$ million. ${ }^{18}$ The company was also indicted for reckless homicide and criminal recklessness in connection with its Pinto designthough a jury acquitted it of these charges. ${ }^{19}$ Similarly, when it was discovered that GM had declined to make a safety-enhancing design change to Chevrolet Malibus (and other A-body cars) based

5 United States v. Carroll Towing Co., 159 F.2d 169, 173 (2d Cir. 1947).

16 See, e.g., Robert D. Cooter \& Thomas S. Ulen, An Economic Case for Comparative Negligence, 61 N.Y.U. L. REV. 1067 (1986); Mark F. Grady, Why Are People Negligent? Technology, Nondurable Precautions, and the Medical Malpractice Explosion, 82 Nw. U. L. REV. 293 (1988); Patrick J. Kelley, The Carroll Towing Company Case and the Teaching of Tort Law, 45 ST. LoUIS U. L.J. 731 (2001); Bruce Chapman, Corporate Tort Liability and the Problem of Overcompliance, 69 S. CAL. L. REV, 1679 (1996); Michael D. Green, Negligence = Economic Efficiency: Doubts >, 75 TEX. L. REV. 1605 (1997); Richard A. Posner, Some Uses and Abuses of Economics in Law, 46 U. CHI. L. REV. 281 (1979).

17 See generally W. Kip Viscusi, Corporate Risk Analysis: A Reckless Act?, 52 STAN. L. REV. 547 (2000) (discussing several cases in which juries awarded high punitive damages after the companies had engaged in risk analysis).

${ }_{18}$ Grimshaw v. Ford Motor Co., 174 Cal. Rptr. 348, 358, 361 (Ct. App. 1981). The trial judge later reduced this $\$ 125$ million award to $\$ 3.5$ million as a condition for denying a new trial. Gary T. Schwartz, The Myth of the Ford Pinto Case, 43 Rutgers L. Rev. 1013, 1017 (1991).

19 See Schwartz, supra note 18 , at 1017. 
on a cost-benefit analysis that showed that the design change was not worth it in economic terms, it, too, was hit with a very large punitive damage award: $\$ 4.8$ billion. $^{20}$

These examples from tort law are especially dramatic because they seem to conflict with formal statements of what negligence law requires. Juries have severely punished corporations for conducting the kind of economic analysis courts have suggested should be used to decide whether the defendant was negligent in the first place. One possible lesson to draw from this state of affairs is that the pull of the moral commitment against knowing killing is so great that even well-established legal formulas, like the test for identifying negligence, do not stand in its way.

In short, there is a well-established legal norm-reflecting a well-established moral commitment-against one person knowingly killing another person. This norm is reflected in traditional laws against murder, in modern regulatory laws prohibiting knowing endangerment, and in old-fashioned tort judgments. This norm reflects, among other things, a widely shared aversion to one person's making the decision about death for another person. It reflects an aversion to one person's calculating in relation to another person that "it's okay by me" if she dies-or, in fact, "it works for me." According to the norm I have described, this kind of calculation not only does not deactivate the norm against knowing killing, but indeed, the calculation itself helps to prove that the norm has been violated. In this regard, recall that some state laws make the definition of murder turn on a pre-killing weighing of the choice whether to kill. $^{21}$

Cost-benefit analysis in the context of life-threatening environmental risks involves a pre-killing weighing of the choice to kill. In this setting, economic costs of pollution-reducing strategies are balanced against the value, stated in terms of dollars,

20 Anderson v. General Motors, Case BC 116926 (Cal. Super. Ct. July 9, 1999); see also Andrew Pollack, \$4.9 Billion Jury Verdict in G.M. Fuel Tank Case, N.Y. TIMES, July 9, 1999, at A8. Members of the jury speaking after the damages were awarded made clear that the economic decision making of GM clearly influenced their decision, with one jury member stating "we're just like

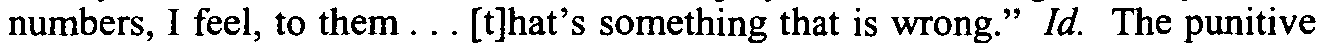
damages award against GM was eventually reduced by the trial judge to $\$ 1.09$ billion. Peter Y. Hong, Judge Cuts Award Against GM to $\$ 1.2$ Billion, L.A. TimEs, Aug. 27, 1999, at B1.

21 See supra note 7 and accompanying text. 
of the people whom the environmental hazards in question will kill. The dollar value of the people who will be killed is determined by considering the monetary value that people place on relatively small risks to themselves, such as increased wage demands for extra risky work. These monetary values for risk are summed to produce a value of a "statistical life"-the value associated with the loss of one life through the imposition of fairly small risks on a population of people.

I think it is obvious that cost-benefit analysis does not redeem knowing killing. Indeed, from what I have just said, it seems clear that using cost-benefit analysis to decide in favor of killing another person makes the killing worse, not better, from a legal and moral perspective.

But in case this is not so obvious, let me explain by way of an example. Imagine a new version of the reality TV show "Survivor." In this show, the contestants who do not make the grade are not just kicked off the show; they are immediately executed. The developers of the show have determined that this program will be wildly popular with the public (in spite of, or perhaps in rebellious reaction to, the culture's moral norm against knowing killing). Indeed, the show will be so popular that its revenues will overwhelm the economic value of the lives lost on the show. Surely no one would assert that it would be appropriate to use cost-benefit analysis to decide whether to go on with this show.

Notice how eerily cost-benefit analysis here matches the definitions of murder I have described. Certainly the cost-benefit analysis involves "premeditation"; that is its purpose-to think about the consequences of a decision, including lives lost, before acting. It also fits neatly with the state laws that look to whether a person who caused a death weighed the consequences before acting. Moreover, cost-benefit analysis in the context of lethal risks is the epitome of knowingly proceeding with life-threatening conduct.

It does not help the TV producers in this case to say that they are not really "after" anybody, that they do not bear ill will against any particular person, that they do not even know who exactly will end up living or dying. What matters is that they have set themselves on a course of conduct that they know will result in human death. The producers can also have all the detailed consent forms in the world, and the forms won't help them; consent is not a 
defense to murder. ${ }^{22}$ And, last, any pecuniary gain on the producers' part, arising from the deaths, only makes it worse for them according to the criminal law of many states. ${ }^{23}$

In this highly stylized case, the practice of cost-benefit analysis runs hard up against the norm against knowing killing. No matter how favorable the cost-benefit ratios may be for lethal reality TV, or snuff films, or modern gladiatorial contests, our legal and moral commitments condemn knowing killing, and they do not make an exception for profitable knowing killing.

But is lethal reality TV analogous to lethal environmental risks? The point of the TV show I have described is to kill someone; without this plot twist, the show is just like any other. People and firms who impose lethal environmental risks on others, however, do not generally make it their point to kill someone. They would just as soon not kill anyone. The people killed by soot, arsenic, asbestos, vinyl chloride, and the like are not the targets of polluters; they are, to use the current euphemism, just collateral damage.

Environmental risks, in other words, pose a case not of malice - the state of mind often associated with knowing killingbut indifference. The perpetrators of environmental killings are often removed in space or time, or both, from the victims of their actions. Polluters might not even know who is exposed to their pollution, let alone who will eventually succumb to it. There is nothing personal, or even purposive, about the harm they cause.

The law, however, and the moral commitments that the law reflects, do not excuse knowing killing even in these circumstances. A knowing killing in pursuit of some end other than death itself-cash, insurance money, notoriety-is no less murder because it seeks that other end. Even killing for the purpose of saving lives-including saving more lives than one destroys-is still generally considered murder. States generally do not recognize a defense of "necessity" in murder cases, ${ }^{24}$ and those 1993).

${ }^{22}$ See, e.g., Gospodareck v. State, 666 So. 2d 835, 842 (Ala. Crim. App.

${ }^{23}$ See, e.g., CONN. Gen. Stat. ANN. $\$ \S 53 \mathrm{a}-54 \mathrm{~b}$ (West 2001); Fla. Stat. $\S 921.141(5)(\mathrm{f})$ (1993); N.C. GEN. STAT. ANN. § 15A-2000(e)(6) (West 2000).

24 See, e.g., People v. Trippet, 66 Cal. Rptr. 2d 559, 563 (Ct. App. 1997) (noting that the necessity defense may be available for any criminal act "except the taking of an innocent human life"); Esquibel v. State, 576 P.2d 1129, 1132 (N.M. 1978) (holding that a duress defense is available "except when the crime 
that do so allow it only in emergencies. ${ }^{25}$ This means that even where the necessity defense is recognized in cases of homicide, it is allowed only when an occasion suddenly arises in which the deaths of a few are required to prevent the deaths of many and not when killing becomes a part of long-term social or economic planning. As to this particular issue, to be sure, moral views can diverge quite appreciably from what the law requires, but even those philosophers who argue in favor of a more forgiving standard for killing undertaken in service of greater life saving take as their premise that life-saving is indeed the goal of the killing. ${ }^{26}$

This cannot be said of the deaths that result from pollution, sanctioned by cost-benefit analysis. Life-saving is not the goal of permitting these deaths; economic efficiency is. While some adventurous souls argue that controlling pollution kills people because it costs money - which could otherwise have been spent by individuals on health care, better nutrition, and the like ${ }^{27}$ - these arguments founder on the weakness of the empirical link between pollution control and human mortality. ${ }^{28}$

Thus, cost-benefit analysis's pre-killing weighing of the decision whether to kill is justified neither by the fact that killing is not the purpose of the underlying enterprise nor by any need to kill a few to save many. Still, many observers likely will reel at the idea that lethal decisions undertaken on the basis of cost-benefit analysis amount to knowing killing. One likely objection will focus on a perceived difference between killing a known person and killing a "statistical" person. To understand the objection, it is necessary to provide a few more details about how cost-benefit analysts translate human lives into dollar terms.

charged is a homicide or a crime requiring intent to kill"); ARIZ. REV. STAT. ANN. § 13-417(c) (2001); KY. REV. STAT. ANN. § 503.030(1) (LexisNexis 1999); Mo. REV. STAT. § 563.026(1) (2000); WIS. STAT. §939.47 (1999).

${ }_{25}$ See Shaun P. Martin, The Radical Necessity Defense, 73 U. CIN. L. REV. 1527, 1567 n.169 (2005) (forty-four states allow the necessity defense only when harm is imminent.); see also Brent D. Wride, Political Protest and the Illinois Defense of Necessity, 54 U. CHI. L. REV. 1070, 1075 (1987).

${ }^{26}$ See generally, e.g., Eric Rakowski, Taking and Saving Lives, 93 ColuM. L. REV. 1063 (1993) (describing conditions under which killing undertaken with the express goal of life saving can be justified).

27 See, e.g., Ralph L. Keeney, Mortality Risks Induced by Economic Expenditures, 10 RiSK ANALYSIS 147, 147-48 (1990); Randall Lutter et al., The Cost-Per-Life-Saved Cutoff for Safety-Enhancing Regulations, 37 ECON. INQUIRY 599, 599 (1999).

${ }_{28}$ See ACKERMAN \& HEINZERLING, supra note 1, at 56-59. 
Everyone, even ardent defenders of cost-benefit analysis, agrees that cost-benefit analysis does not apply when we confront an identified person with certain or almost-certain death. Though economists have long used "willingness-to-pay" as the measure of value for cost-benefit purposes, ${ }^{29}$ this metric does not work with certain or almost-certain death. If I ask you how much you are willing to pay to avoid certain death, your answer will likely depend wholly on your ability to pay; the more you have, the more you will pay. If I ask you how much money you are willing to accept in order to accept death, I think you are likely to tell me to go away, to tell me that you are not in the market for certain death right now. Thus, whether formulated in the willingness-to-pay or willingness-to-accept framework, this inquiry goes nowhere in the context of certain death. Thus, economists have been willing to concede that when an identified person is threatened with death, we do not pause to do cost-benefit analysis before trying to rescue her; ${ }^{30}$ we don't calculate the costs of saving the little girl in the well, we just rush to the scene and do what we can to save her.

To get around this problem, economists invented the "statistical" life. It is harder than one might imagine to pin down exactly what is meant by "statistical life." ${ }^{\text {A }}$ At the least, a statistical life is an unidentified life; we do not know who will die when a statistical life hangs in the balance.

But why should a lack of knowledge about the ultimate victims of lethal conduct justify differential treatment of statistical and non-statistical lives? Suppose I randomly distribute lethal but undetectable poison, causing a fatal reaction indistinguishable from a deadly case of the flu, in a small percentage of a large population. Should the wisdom of my conduct be evaluated according to cost-benefit analysis? Isn't what I have done murder, according to the definitions we have just considered? Indeed, perhaps the defining act of knowing killing of our timeterrorism-involves just the sort of unidentified victims I have

${ }^{29}$ See, e.g., Roland N. McKean, Products Liability: Trends and Implications, 38 U. CHI. L. REV. 3, 31-33 (1971); Cass R. Sunstein, Lives, Life-years, and Willingness to Pay, 104 COLUM. L. REV. 205, 226 (2004).

30 See, e.g., W. KiP Viscusi, Fatal Tradeoffs: Public and Private RESPONSIBILITIES FOR RISK 21, 29 (1992).

31 See generally Lisa Heinzerling, The Rights of Statistical People, 24 HARV. ENVTL. L. REV. 189 (2000) (describing the difficulties posed by the concept of the statistical life). 
described. In short, I do not think the identifiability of the victims of lethal conduct gets us very far in explaining how decisions made on the basis of cost-benefit analysis are different from knowing killing. ${ }^{32}$

Another way to define statistical life is as the collection of fairly small individual risks within a population. Here is how the economist Kip Viscusi describes statistical lives:

[W] hen assessing the benefits of risk reduction, the pertinent value is the willingness to pay for the risk reduction. What we are purchasing with our tax dollars is not the certainty of survival. Rather, it is the incremental reduction in the probability of an adverse outcome that might otherwise have affected some random member of our community. ${ }^{33}$

Some who advocate this view of the statistical life prefer the term "micromort," which is defined as a "one in one million chance of death." 34 Perhaps a micromort would be valued at $\$ 5$. If one million people were each willing to pay $\$ 5$ to avoid such a risk, then we could say that they would collectively be willing to pay $\$ 5$ million to avoid one death. But, the micromort advocates would remind us, we are still valuing risk, not life itself. Since life itself is not involved, neither is knowing killing.

Simply calling what we are valuing "risk" (or "micromorts") rather than "life," does not change the fact that real lives, not statistical lives, hang in the balance. There are no statistical people; there are only real people. If a person dies due to an environmental hazard, a real person dies-even if we do not know who she is, and even if many other people were also exposed to the hazard that killed her. For the distinction between statistical and non-statistical lives to hold any normative significance, we must believe that in all cases to which it is applied, no one will die as a result of the hazard we are considering. If no one will die, then no life is lost, and we might as well describe the persons we expected to die as "statistical people." But if anyone dies-anyone-then the contrivance no longer works. Someone has died, that person was a real person, and our inability to identify that person by name

32 For an excellent discussion, see John Broome, Trying to Value a Life, $9 \mathrm{~J}$. PUB. ECON. 91, 92 (1978).

33 VISCUSI, supra note 30, at 19.

34 A term first used in Ronald A. Howard, On Making Life and Death Decisions, in SocIETAL RISK ASSESSMENT: How SAFE Is SAFE ENOUGH? 89, 99 (Richard C. Schwing \& Walter A. Albers, Jr. eds., 1980). 
does not change the fact that she has died.

To illustrate: suppose I activate a time bomb which, by my best calculations, will explode at a moment when the location of the bomb is packed with people. I miscalculate. Only one person is nearby, and only one person dies. The fact that my actions led to only one death rather than many does not make that one death any less the result of knowing killing.

Many have argued that risk assessment overstates risk ${ }^{35}$ (though others point out that it also understates risk in important ways $^{36}$ ). However, the argument that estimated lives lost should be lower than risk assessments predict is different from saying it should be zero. In the kinds of large-scale decisions in which costbenefit analysis plays a prominent role, it is improbable that risk assessments predicting lives lost in the absence of regulation are so flawed that the prediction should be zero lives lost rather than some smaller but still positive number.

In sum, the contrivance of "statistical life" does not justify allowing polluters to evade the norm against knowing killing. Nevertheless, several objections remain to my project of trying to activate the norm against knowing killing in the context of environmental hazards.

First, even if scientists agree that some death will result from a certain pollutant, what if the person who decides to release the pollutant does not believe the scientists? Can a person have acted "knowingly" in causing a death if she sincerely believed no death would occur? I have a friend who worked as a lawyer representing tobacco companies. During his time working for tobacco companies, he came to believe that nicotine was not addictive. There is a large psychological pressure to believe one's actions are not hurting others. But it cannot be that erecting psychological barriers to conscious belief absolves one of the moral burden of avoiding consequences that are, psychological factors aside, practically certain to follow from one's actions. If one's hold on reality is so tenuous that one cannot differentiate right from wrong, then one's harmful actions might be excused from a moral and legal perspective. There is, however, a large difference between

35 For a lucid account of major critiques, see STEPHEN BREYER, BREAKING THE VICIOUS CIRCLE: TOWARD EFFECTIVE RISK REGULATION 42-50 (1993).

36 See, e.g., Adam N. Finkel, A Second Opinion on an Environmental Misdiagnosis: The Risky Prescriptions of Breaking the Vicious Circle, 3 N.Y.U. ENVTL. L.J. 295, 340-52 (1995). 
beliefs predicated on avoiding cognitive dissonance and beliefs predicated on the conviction that, say, you must shoot a person because God told you it is in that person's best interests to do so.

In the corporate contexts in which many decisions about pollution are made, knowledge becomes even more problematic. Individual actors might convince themselves that someone else is taking care of whatever hazard they might identify. ${ }^{37}$ Or they might convince themselves that if no one is in fact taking care of the hazard, there must be no hazard. Knowledge dissipates in collective settings. Sometimes, however, knowledge dissipates due to deliberate conduct on the part of individuals; individuals might choose to compartmentalize knowledge so that everyone can plausibly deny responsibility for the harmful consequences of the collective enterprise. ${ }^{38}$ Here, too, it would be difficult to argue that one can escape the moral and legal implications of lethal conduct simply by remaining willfully blind to them.

Another objection to my effort to bring decisions about lethal environmental hazards based on cost-benefit analysis within the ambit of knowing killing might be that people consent all the time to increased risk, and this consent should acquit polluters of moral and legal responsibility for deaths that occur due to increased risk from pollution. The trouble is that "consent," or "willingness-topay" in the cost-benefit context, is manufactured by reference to the behavior of other people in different circumstances, often circumstances in which free and knowing consent is not even clear, as in workplace risks. Thus, current cost-benefit analyses use wage premiums discerned in studies using data from the 1970s - data on accident risks, almost exclusively involving men, in a setting in which there is (by hypothesis) already a market for risk - to decide how much arsenic to allow in drinking water in the new century. ${ }^{39}$ Cost-benefit analysts call this operation "benefits transfer" and explain that it is necessitated by resource constraints. $^{40}$ But cost-benefit analysis falls apart without this

37 See, e.g., BIBB LATANÉ \& JOHN M. DARLEY, THE UNRESPONSIVE BYSTANDER: WHY DOESN'T HE HELP? 90 (1970).

38 For a discussion of the phenomenon of "moral distancing," see Benedict Carey, In the Execution Chamber, the Moral Compass Wavers, N.Y. TIMES, Feb. 7, 2006, at F1.

${ }^{39}$ See Lisa Heinzerling, Markets for Arsenic, 90 GEO. L.J. 2311, 2316-29 (2002).

40 For explanation of this technique, see Amy Sinden, The Economics of Endangered Species: Why Less Is More in the Economic Analysis of Critical 
device. If analysts needed real consent to do their work, they would face the problem that some people wouldn't sell their entitlement to be free from whatever risk was being marketed. Indeed, results of previous studies on individual behavior in risky settings suggest that a substantial number of people simply refuse to participate in certain markets for risk. ${ }^{41}$ Thus consent cannot be a catch-all justification for knowing imposition of lethal risks; often enough it simply does not exist.

When people expose other people to environmental hazards that are practically certain to cause some of the exposed people to die, the former have engaged in knowing killing and thus in presumptively morally problematic conduct. There is no obvious way around this conclusion. Undoubtedly many readers will believe that this argument proves too much, that it makes killers out of the people who produce the things-electricity, oil, chemicals-that bring good things to life. My main object, however, has not been to settle the question of what should be done when we find that our common practices run up against the norm against knowing killing; it may be that we need to think about what would justify knowing killing in the circumstances I have described. My main object, rather, has been to suggest that our discussion of environmental policy has been impoverished by its lack of attention to our underlying moral commitments. We might well decide that much lethal pollution is acceptable from a moral perspective, but we need to have an argument for why this is so. For too long, we have elided the moral content of decisions about the environment by talking about deaths caused by environmental problems in amoral terms. It seems morally unproblematic, for example, to cause the death of a "statistical person." But once we recognize that statistical people do not exist, that real people are at stake in our decisions about pollution, then we can begin to have a more honest and productive discussion about the moral duties we owe to people we place at risk.

Habitat Designations, 28 HARV. ENVTL. L. REV. 129, 182 n.238 (2004).

${ }^{41}$ See W. Kip Viscusi et al., An Investigation of the Rationality of Consumer Valuations of Multiple Health Risks, 18 RAND J. ECON. 465, 477 (1987) (reporting that in an economic survey regarding household products, the vast majority of parents with children living in their homes refused to accept discounted or free riskier products). 